\title{
Jakub Pruś
}

\section{Semantyczna teoria prawdy a antynomie semantyczne}

\author{
Semantic Theory of Truth vs. Semantic \\ Antinomies
}

\begin{abstract}
Abstrakt
W poniższym artykule przedstawiona została dyskusja z zarzutami antynomiorodności wysuwanymi przeciwko semantycznej teorii prawdy Alfreda Tarskiego. Choć Tarski pokazał, że jego teoria rozwiązuje paradoks kłamcy, to w wieku XX i XXI powstało wiele rozbudowanych antynomii semantycznych, które są skierowane przeciwko tej koncepcji, a jej autor w większości pozostawił je bez odpowiedzi. Niniejszy artykuł skupia się na analizie tych zarzutów, a następnie na wykazaniu, że semantyczna teoria prawdy broni się przed tymi antynomiami. Okazuje się tym samym nie tylko, że koncepcja prawdy Tarskiego pozostaje bezsprzeczna, ale także, że jest to wciąż jedna z najbardziej optymalnych możliwości uniknięcia paradoksów i pozostania w obrębie logiki klasycznej. Punkt wyjścia do przedstawionych tutaj analiz stanowią definicja prawdy zaprezentowana przez Tarskiego w 1933 roku oraz bardziej współczesne dyskusje nad nią, w tym antynomie, które sformułowane zostały przeciwko niej w postaci zarzutów. Cel artykułu jest więc podwójny: po pierwsze, wykazanie, że rozwiązanie Tarskiego pozostaje aktualne i jest odporne na owe antynomie. Po drugie, udowodnienie, że takie rozwiązanie pozwala pozostać w logice klasycznej, to jest zachować zasadę dwuwartościowości, niesprzeczności
\end{abstract}


oraz zasadę wyłączonego środka, jednocześnie unikając paradoksu kłamcy i jemu podobnych.

Słowa klucze: antynomia semantyczna, konwencja T, schemat T, semantyczna teoria prawdy, paradoks kłamcy, prawda, Tarski Alfred

\begin{abstract}
The paper presents Alfred Tarski's debate with the semantic antinomies: the basic Liar Paradox, and its more sophisticated versions, which are currently discussed in philosophy: Strengthen Liar Paradox, Cyclical Liar Paradox, Contingent Liar Paradox, Correct Liar Paradox, Card Paradox, Yablo's Paradox and a few others. Since Tarski, himself did not addressed these paradoxes-neither in his famous work published in 1933, nor in later papers in which he developed the Semantic Theory of Truth-therefore, We try to defend his concept of truth against these antinomies. It is demonstrated that Tarskian theory of truth is resistant to the paradoxes and it is still the best solution to avoid the antinomies and remain within a classical logic, that is, accepting the laws of noncontradiction, excluded middle, and the principle of bivalence. Thus, the goal of the paper is double-firstly, to show that none of the versions of the Liar Paradox's is a serious threat to Tarski's concept of truth, and secondly, that Semantic Theory of Truth allows to remain within classical logic, and at the same time, avoid antinomies-which makes it the most attractive among classical theories of truth.
\end{abstract}

Keywords: liar paradox, semantic antinomy, semantic theory of truth, T-convention, truth, Alfred Tarski

Jednym z niepodważalnych osiągnięć Alfreda Tarskiego w dziedzinie rozumienia pojęcia prawdy jest uniesprzecznienie go - a dokładniej uczynienie go odpornym na antynomię kłamcy oraz inne antynomie semantyczne. W tej pracy zostanie przedstawione rozwiązanie tych antynomii metodą Tarskiego. Jednak, o ile Tarski zaprezentował swoje rozwiązanie dla „klasycznej” antynomii kłamcy, o tyle nie zdołał poświęcić uwagi wszystkim innym antynomiom, które stanowią poważne zarzuty przeciwko semantycznej teorii prawdy - część z nich została sformułowana dopiero po jego śmierci. Przedmiotem analizy będą więc różne antynomie, które stanowią rozwinięcie paradoksu kłamcy: „poprawny” paradoks kłamcy, „wzmocniony” paradoks kłamcy, „kołowy” paradoks kłamcy oraz „przypadkowy” paradoks kłamcy. Niepodobna wymienić 
je wszystkie, ale te ważniejsze zostaną niżej rozważone w świetle teorii prawdy Tarskiego. Przed rozpoczęciem szczegółowych analiz trzeba jednak postawić jeszcze jedno pytanie, mianowicie czy paradoks kłamcy i w ogóle antynomie semantyczne to poważne problemy dla logiki lub filozofii? Po zadaniu tego pytania przedstawiona zostanie krótka charakterystyka paradoksu kłamcy i rozwiązania Tarskiego. Następnie dokładniej omówione będą cztery antynomie semantyczne dające się określić jako zmodyfikowane wersje paradoksu kłamcy.

\section{Znaczenie antynomii semantycznych dla logiki}

Dla niektórych filozofów problem kłamcy to raczej „sztuczny” problem, którym ani logicy, ani filozofowie nie powinni się zajmować. Wszak przez ową sprzeczność „żaden most się jeszcze nie zawalił”. Podobnie uważał Ludwig Wittgenstein:

Cóż szkodzi sprzeczność powstająca wtedy, gdy ktoś mówi: „Kłamię A więc nie kłamię - A więc kłamię - itd."? Chodzi mi o to: czy nasz język staje się mniej użyteczny przez to, że można w tym wypadku z pewnego zdania wywnioskować wedle zwykłych reguł jego przeciwieństwo, a z tego znów tamto pierwsze zdanie? - Bezużyteczne jest samo to zdanie, podobnie jak owo wnioskowanie. Dlaczego jednak nie mielibyśmy go przeprowadzać? - Jest to jałowa sztuka!²

W odpowiedzi na takie stanowisko można przywołać fragment z Prawdy i dowodu Alfreda Tarskiego:

W literaturze poświęconej antynomiom napotkać można dwa diametralnie przeciwne podejścia do tego zjawiska. Przy pierwszym z nich zaleca się nie zwracać na antynomie zbyt wiele uwagi i traktować je jako złośliwe, lecz niepoważne żarty, jako sofizmaty skomponowane głównie pour épater les bourgeois ${ }^{3} \mathrm{i}$ w najlepszym razie świadczące o pomysłowości ich autorów.

1 Andrew Hodges, Turing (Warszawa: Amber, 1998), cyt. za: Bartosz Brożek, „Rola paradoksu kłamcy w konstrukcji logicznych teorii prawdy”. Zagadnienia Filozoficzne w Nauce 15 (2002): 5.Używam tu numeracji z elektronicznej wersji artykułu, która nie pokrywa się z wersją wydrukowaną w czasopiśmie: http://www.obi.opoka.org/ zfn/030/zfn03004Brozek.pdf (dostęp: 14.12.2021]

2 Ludwig Wittgenstein, Uwagi o podstawach matematyki, tłum. Marcin Poręba, (Warszawa: Spacja, 2001), 95.

3 fr. aby zaskakiwać mieszczaństwo [przyp. J.P.]. 
Podejście przeciwne jest charakterystyczne dla pewnych myślicieli XIX wieku i jest wciąż jeszcze (lub było do niedawna) programowo uprawiane w pewnych częściach kuli ziemskiej. Przy tym podejściu antynomie stanowią bardzo istotny element ludzkiego myślenia, muszą się one raz po raz pojawiać w naszej działalności intelektualnej, a ich obecność jest podstawowym źródłem rzeczywistego postępu.... Kiedykolwiek to się zdarzy, musimy podać głębokiej rewizji nasz sposób myślenia, odrzucić pewne przesłanki, w które wierzyliśmy, lub ulepszyć formy rozumowania, których dotąd używaliśmy ${ }^{4}$.

W kontekście przytoczonych rozważań można stwierdzić, że paradoks kłamcy ma dla Tarskiego podwójny charakter. Po pierwsze, jest czymś, wobec czego nie można pozostawać obojętnym, gdyż - parafrazując jego słowa napisane gdzie indziej - „zostaliśmy zmuszeni do uznania fałszywego zdania i nie możemy się z tym pogodzić, jeśli swoją pracę traktujemy poważnie"5. Po drugie, jest to okazja do tego, aby poprawić swój sposób myślenia o rzeczywistości - analizując historię rozwoju logiki i matematyki, łatwo dojść do wniosku, że to właśnie antynomie odegrały „pierwszoplanową rolę w ustanowieniu podstaw współczesnych nauk dedukcyjnych”6. Sam paradoks kłamcy „doprowadził do wielu interesujących rezultatów i wyrafinowania metod analizy logicznej”7. Podobnie jak Tarski nie mógł pozostać niewzruszony wobec sprzeczności wynikającej z antynomii kłamcy, tak i tutaj zostanie podjęta próba rozważenia jej zmodyfikowanych wersji.

\section{Możliwe sposoby rozwiązania antynomii kłamcy}

Oto najprostsza wersja interesującej nas antynomii, która jest przekształceniem starożytnego paradoksu sformułowanego w IV wieku przed Chrystusem przez Eubulidesa ${ }^{8}$ :

4 Alfred Tarski, „Prawda i dowód” w: idem, Pisma logiczno-filozoficzne, t. I, (Warszawa: Wydawnictwo Naukowe PWN, 1995), 308.

5 Alfred Tarski, „Semantyczna koncepcja prawdy i podstawy semantyki”, w: idem, Pisma logiczno-filozoficzne, t. 1, 241.

6 Tarski, „Semantyczna koncepcja prawdy i podstawy semantyki”, 242.

7 Jan Woleński, Epistemologia (Warszawa: Wydawnictwo Naukowe PWN, 2005), 205.

8 „Najsłynniejsze sformułowanie paradoksu kłamcy pochodzi od Savonaroli, który zagadkę tę streścił w lapidarnym zdaniu Hoc est falsum”, vide: Brożek, „Rola paradoksu kłamcy w konstrukcji logicznych teorii prawdy", 2. 
To zdanie jest fałszywe.

Zaimek wskazujący „to” może rodzić pewne zastrzeżenia, więc lepiej będzie użyć ścisłego oznaczenia (Tarski do oznaczania zdań w swoich rozważaniach używał numeru stron i wiersza $)^{9}$ :

(I) Zdanie (I) jest fałszywe.

Powyższe zdanie prowadzi wprost do sprzeczności, gdyż jeśli przyjmiemy, że jest ono prawdziwe, dojdziemy do wniosku, że jest fałszywe, a jeśli założymy jego fałszywość, to trzeba będzie przyznać mu wartość prawdy. Wynika to z tego, że zdanie to odsyła samo do siebie lub mówiąc inaczej - „zapętla” swoje znaczenie, jednocześnie wprowadzając fałszywość, co prowadzi do sprzeczności ${ }^{10}$. Dlatego właśnie takie zjawisko nazywa się również „pętlą semantyczną” albo „błędnym kołem”" Żeby zlikwidować antynomię, trzeba w jakiś sposób „otworzyć” tę pętlę, co właśnie - jak to zostanie pokazane - zrobił Tarski.

Aby uniknąć paradoksu, możliwe są trzy rozwiązania: (A) wyrugowanie z języka wyrażeń samozwrotnych, czyli takich, które odnoszą się same do siebie; (B) odrzucenie logiki klasycznej i przyjęcie jakiejś paralogiki, która nie zakłada zasady niesprzeczności; (C) uznanie takiego wyrażenia za źle sformułowane z powodu pomieszania w nim różnych poziomów języka ${ }^{12}$.

Możliwość (A) jednak wcale nie rozwiązuje problemu. Oto paradoks sformułowany przez brytyjskiego matematyka, Philipa Jourdaina, nazywany również „paradoksem kartki papieru” lub „podwójnym paradoksem kłamcy"13:

9 Tarski, „Prawda i dowód”, 303.

10 Paradoks nie pojawiłby się, gdyby zdanie stwierdzało prawdziwość - wciąż jednak byłoby samozwrotne.

11 Vide: referat Jana Woleńskiego wygłoszony na seminarium „Filozofia w nauce” zorganizowanym $\mathrm{z}$ okazji siedemdziesiątych piątych urodzin księdza profesora Michała Hellera w 2011 roku: https://www.youtube.com/watch?v=cR9DU9FkAJo (dostęp: 10.11.2019].

12 W ostatnich miesiącach ukazały się przełomowe prace, które sugerują inną możliwość rozwiązania paradoksu kłamcy i jego pochodnych (vide: Konrad Rudnicki, Piotr Łukowski, "Psychophysiological Approach to the Liar Paradox: Jean Buridan's Virtual Entailment Principle Put to the Test", Synthese 198 (2019); Piotr Łukowski, "Content Implication and Yablo's Sequence of Sentences", Logic and Logical Philosophy 29 (2020).

13 W literaturze anglosaskiej używa się nazw: Jourdain Paradox, Card Paradox, Postcard Paradox lub Double Liar Paradox. 
Poniższe zdanie jest prawdziwe.

Powyższe zdanie jest fałszywe.

W ten sposób także dochodzi się do sprzeczności, nie wykorzystując przy tym autoreferencji. Co więcej, często w języku naturalnym bezsprzecznie używa się zdań samozwrotnych, wcale nie popadając w sprzeczność - pojawia się ona tylko w szczególnych sytuacjach, gdy w zdaniu orzeka się o fałszywości tego właśnie zdania ${ }^{14}$. Natomiast wypowiedź „To, co teraz mówię, jest prawdą” wcale nie jest antynomiorodna, mimo że tworzy pętlę semantyczną ${ }^{15}$. Na przykładzie paradoksu Jourdaina widać wiec wyraźnie, iż zrezygnowanie ze zdań samozwrotnych wcale nie rozwiązuje problemu, a w dodatku można sobie bez większych trudności wyobrazić używanie takich zdań samozwrotnych, które funkcjonują w języku bez rodzenia antynomii.

Możliwość (B) polega na odrzuceniu zasady niesprzeczności, a więc de facto na akceptacji sprzeczności. Da się to zrobić na kilka sposobów: (a) poprzez zamianę logiki klasycznej na jakąś paralogikę, która zawiera sprzeczność, (b) przez przyjęcie logiki wielowartościowej (na przykład logiki trójwartościowej Jana Łukasiewicza) i (c) poprzez ignorowanie antynomii, pozostając jednocześnie w obrębie logiki klasycznej. Żadne z tych rozwiązań nie wydaje się jednak zadowalające.

Sposób (a) można z łatwością odrzucić, powołując się na Jana Dunsa Szkota, który wykazał, że na podstawie dwóch sprzecznych zdań można wyprowadzić każde zdanie. Borkowski pisze, że „system zawierający antynomię jest bezużyteczny z poznawczego punktu widzenia, gdyż można w nim udowodnić wszystkie zdania fałszywe"16. Sposób (b) również nie wytrzymuje próby: przyjąwszy system logiki trójwartościowej, w której zdania mają wartość albo 0 , albo 1/2, albo 1, rozważmy zmodyfikowaną wersję (I):

(II) Zdanie (II) nie jest prawdziwe.

14 Tarski podaje przykład zdania, które orzeka fałszywość i nie prowadzi do antynomii, np. „Niektóre zdania w tej pracy są fałszywe”, vide: Tarski, „Prawda i dowód”, 300.

15 Ten przypadek określa się „prawdomównym” (Truthteller) i choć nie jest wersją antynomii kłamcy i nie prowadzi do sprzeczności, to również można powiedzieć, że stwarza on „pętlę semantyczną”. Jeśli chce się bowiem sprawdzić prawdziwość tego zdania, to odsyła ono nie do jakiegoś stanu rzeczy, lecz do siebie samego, a więc zapętla się, lecz nie używając terminu fałszywości lub nie-prawdziwości, nie tworzy paradoksu (vide: Brożek, „Rola paradoksu kłamcy w konstrukcji logicznych teorii prawdy”, 3-4).

16 Ludwik Borkowski, Wprowadzenie do logiki i teorii mnogości (Lublin: Towarzystwo Naukowe Katolickiego Uniwersytetu Lubelskiego, 1991), 214. 
Jeśli zdaniu (II) przyznana zostanie wartość 1 (prawda), to będzie trzeba przyjąć, że ma ono wartość $1 / 2$ („półprawda”) albo 0 (fałsz). W ten sposób dochodzi się do sprzeczności. Podobnie, jeśli przyzna się mu wartość $1 / 2$ albo 0 , to trzeba w konsekwencji uznać, że ma ono także wartość 1 (stanie się prawdziwe). Zatem każda z tych możliwości prowadzi do sprzeczności. Stąd należy wyciągnąć wniosek, że logika trójwartościowa (i inne logiki wielowartościowe) nie rozwiązują paradoksu kłamcy i dlatego trzeba odrzucić sposób (b).

Jest jeszcze trzecia możliwość (c), czyli ignorowanie antynomii semantycznych i pozostanie w obrębie logiki klasycznej, jak zrobił to na przykład Wittgenstein w przytoczonym wcześniej cytacie. Przeciwko temu rozwiązaniu można wysunąć argument, że taka wyjątkowa akceptacja sprzeczności może być niewykorzystaną okazją dla rozwoju nauki, która rozwija się dzięki odkrywaniu paradoksów (jak to zauważył cytowany wcześniej Tarski) oraz, że ze sprzeczności można wyprowadzić każde zdanie, co jest niedopuszczalne w naukach dedukcyjnych (przytoczony cytat Borkowskiego). Stąd należy wnioskować, że sposób (c) nie oferuje zadowalającego rozwiązania antynomii kłamcy. Tym samym odrzucona zostaje także możliwość rozwiązania paradoksu przez akceptację sprzeczności (b), co pozostawia już tylko możliwość (iii) - czyli dyskwalifikację takich zdań jak (I) i (II). To zaś można zrobić przez rozdzielenie poziomów w języku oraz zaakceptowawszy zasadę jednorodności języka. Tę drogę - jak to już było powiedziane - wybrał Alfred Tarski.

\section{Rozwiązanie antynomii kłamcy w semantycznej teorii prawdy}

Poniżej zostanie skrótowo przedstawione rozwiązanie paradoksu kłamcy przez Tarskiego. Choć sam filozof budował pojęcie prawdy tylko dla języków sformalizowanych, to jednak jego wyniki są również wartościowe dla języka naturalnego. W swojej nowatorskiej pracy z 1933 roku zaproponował on procedurę definiowania prawdy, postawił jednak pewne warunki ${ }^{17}$ : (I) należy mówić o prawdziwości tylko w konkretnym języku (relatywizacja prawdy do języka ${ }^{18}$ ); (II) trzeba odróżniać wyraże-

17 Tarski mocno akcentował cztery pierwsze zasady w swoich pracach, co wcale nie było oczywiste w latach trzydziestych, np. w liście Tarskiego do Neuratha (vide: Alfred Tarski, „List Alfreda Tarskiego do Ottona Neuratha”, w idem, Pisma logiczno-filozoficzne, t. 1,210 .

18 „(..) musimy więc zawsze odnosić pojęcie prawdy, podobnie jak pojęcie zdania, do określonego języka. Jest bowiem jasne, że to samo wyrażenie, które jest zdaniem 
nia języka, którego się używa do budowania definicji, to jest metajęzyka, od wyrażeń języka, dla którego ta definicja jest formułowana - tzw. stratyfikacja języka ${ }^{19}$; (III) nie można mieszać wyrażeń z różnych stopni języka w budowie zdania - tzw. zasada jednorodności semantycznejej (IV) prawdziwość można orzekać tylko w metajęzyku, który jest bogatszy od języka, o którym mowa; (V) język, dla którego buduje się definicję powinien mieć wyraźnie określoną strukturę: ustalony słownik wyrażeń i reguły budowania wyrażeń, aby móc używać nazw jednostkowych w definicji prawdziwości - tzw. formalizacja języka ${ }^{21}$.

Skrótowo można przedstawić te ustalenia w następujący sposób: J, MJ i MMJ, gdzie kolejno J jest językiem przedmiotowym, MJ jest metajęzykiem J, a MMJ jest metajęzykiem MJ. Oznacza to, że J nie posiada predykatu prawdziwości, MJ posiada predykat prawdziwości, ale tylko dla J - nazwijmy go $\mathrm{T}_{1}$ - a MMJ posiada predykat prawdziwości dla $\mathbf{M J}$ nazwijmy go $\mathrm{T}_{2}$, zaś MMMJ będzie zawierał $\mathrm{T}_{3} \mathrm{i}$ tak dalej. $\mathrm{T}_{1}$ używa się do określania prawdziwości zdań $\mathbf{J}$, choć $\mathrm{T}_{1}$ nie należy do J, zaś używa się $\mathrm{T}_{2}$ do określania prawdziwości zdań $\mathbf{M J}$, choć $\mathrm{T}_{2}$ nie należy do $\mathbf{M J}$. Spójrzmy teraz na paradoks kłamcy wyrażony w (2):

(2) Zdanie (2) nie jest prawdziwe.

Jak można interpretować to zdanie? Nie można go zaliczyć do J, bo zawiera predykat „prawdziwe”. Wynika to z hierarchii języków i konwencji $T$, którą proponuje Tarski: zasada jednorodności semantycznej mówi, że nie można używać wyrażeń $z$ innego poziomu języka, a wedle zasady ujednostajniania semantycznego, gdy rozważa się jakieś zdanie, zawsze trzeba przyjąć taki poziom języka (kategorię semantyczną), w którym

prawdziwym $w$ jednym języku, $w$ innym może być fałszywe lub bezsensowne" Tarski, „Semantyczna koncepcja prawdy i podstawy semantyki”, 231. Vide: znaczenie tego pomysłu w artykule Adama Nowaczyka, „Co naprawdę powiedział Tarski o prawdzie w roku 1933?”, w Alfred Tarski: dedukcja i semantyka (Warszawa: Wydawnictwo Naukowe Semper, 2003), 62-63.

19 Vide: Alfred Tarski, „Pojęcie prawdy w językach nauk dedukcyjnych”, w idem, Pisma logiczno-filozoficzne, t. I, 34.

20 Vide: Woleński, Epistemologia, 207.

21 Słuszna jest uwaga, że szanse na zbudowanie trafnej definicji są tym większe, im mniej skomplikowany jest język, vide: Adam Jonkisz, „Semantyczne ujęcie klasycznej koncepcji prawdy" w O prawdzie, t. 1, (Cieszyn: Koło Filozoficzne Uniwersytetu Śląskiego w Cieszynie, 1992), 9, 21. 
interpretacji podlegają wszystkie jego wyrażenia ${ }^{22}$. Interpretowanie (2) w J można więc zobrazować następująco, niech zdanie $f$ będzie zdaniem języka polskiego:

(f) To zdanie nie jest vrai.

Każdy, kto jest zaznajomiony z językiem polskim (i choć trochę z francuskim), zauważy, że zdanie to nie zostało sformułowane wyłącznie w tym języku, bo zawiera wyrażenie z innego języka - francuskiego. Nie jest to więc poprawne wyrażenie języka polskiego, bo - choć wszystkie znaki należą do alfabetu - słowo vrai nie jest zbudowane według syntaktyki języka polskiego. Analogicznie predykat „prawdziwe” nie może funkcjonować w J, bo nie jest „Poprawnie Zbudowanym Wyrażeniem” języka J, co dalej będę oznaczał jako PZW ${ }^{23}$.

Może więc trzeba interpretować zdanie (2) jako należące do MJ? Jako że MJ operuje predykatem prawdziwości $\mathrm{T}_{1}$, można by je sformułować następująco:

(3) $\neg \mathrm{T}_{1}(3)$

Wówczas również napotyka się podobną trudność - $\mathrm{T}_{1}$ może stosować się tylko do wyrażeń należących do J, nie do MJ, więc w tym zdaniu predykat prawdziwości nie może związać zdania (3), gdyż wówczas również łamałby konwencję $T$. Stąd należy wyciągnąć wniosek, że (3) również nie jest PZW w MJ. W ten sposób Tarski mógł odrzucić antynomię kłamcy, gdyż w kontekście obu z rozważanych poziomów języka trzeba je uznać za niepoprawnie zbudowane wyrażenie, czyli naruszające zasady właściwej budowy zdań. Co więcej, w ten sposób została wybroniona klasyczna teoria prawdy (veritas est adequatio intellectus et rei), której STP jest odmianą ${ }^{24}$.

22 Mówi się też o metodzie ujednostajniania semantycznego zmiennych (vide: Jonkisz, „Semantyczne ujęcie klasycznej koncepcji prawdy”, 18).

23 Tę samą diagnozę można z powodzeniem postawić antynomii Russella (zbiór wszystkich zbiorów, które nie są własnymi elementami, jest i jednocześnie nie jest własnym elementem). Paradoks wynika z pomieszania kategorii logicznych indywiduum i klasy. Aby rozwiązać tę antynomię w teorii mnogości, trzeba zbudować hierarchię tzw. typów logicznych (Woleński, Epistemologia, 199).

24 Dokładną klasyfikację klasycznych teorii prawdy oraz ich relację do korespondencyjnej teorii prawdy omawiam w artykule „Teorie prawdy: klasyczna, korespondencyjna i semantyczna - próba uściślenia relacji”, Rocznik Filozoficzny Ignatianum 24/2 (2018). 


\section{Modyfikacje antynomii kłamcy}

„Klasyczna” antynomia kłamcy doczekała się wielu modyfikacji i rozwinięć, które nierzadko zmuszały logików zajmujących się tym problemem do opracowywania nowych sposobów ominięcia paradoksu. Dalej rozważam najbardziej popularne wersje antynomii kłamcy i innych antynomii semantycznych, które - moim zdaniem - są najbardziej zagrażające dla rozwiązania zaproponowanego w semantycznej teorii prawdy Tarskiego.

$\mathrm{Na}$ samym początku warto jednak postawić jeszcze jedno pytanie: czy jest sens zajmować się kolejnymi wyszukanymi wersjami paradoksu kłamcy? Paradoks ten został rozwiązany, po co więc szukać na nowo „dziury w całym”? Odpowiedź na tę wątpliwość została już zawarta wyżej - takie podejście zdaje się sprzeczne z ,ideałem nauki”, gdyż może się okazać, że paradoksy te obalą coś, co jest uważane za słuszne, i wymuszą zmianę w obecnym kształcie tez nauki. Skoro antynomie odgrywają w logice i naukach dedukcyjnych ważną rolę, to paradoks kłamcy również powinien stanowić wyzwanie dla osób zajmujących się tą tematyką trzeba więc uznać wszystkie modyfikacje antynomii kłamcy za poważne problemy domagające się rozwiązania. Jeśli bowiem wypracowana teoria prawdy ma być poprawna $w$ tym sensie, że jest odporna na paradoks kłamcy, to powinna również być odporna na wszystkie jego modyfikacje (i inne antynomie). Dodatkowym, jeśli nie ważniejszym, powodem do podjęcia się tego problemu jest to, że poprawna teoria prawdy musi uniknąć takich paradoksów, bo inaczej człowiek nigdy nie zbliży się do rozumienia prawdy czy prawdziwości, a tak długo jak antynomia kłamcy daje się do teorii prawdy stosować, tak długo nie można powiedzieć, że to rozumienie posiadamy. Dalej przedstawione zostaną wybrane wersje paradoksu kłamcy i porównane z STP Tarskiego, celem wykazania, że STP jest poprawną teorią prawdy w tym sensie, że nie jest antynomiorodna - przynajmniej na podstawie zarzutów, które się jej przedstawia w postaci analizowanych paradoksów.

\section{„Poprawny" paradoks kłamcy}

Pierwsza możliwość może nasunąć się po zapoznaniu się z rozwiązaniem „klasycznego” paradoksu kłamcy. Polega ona na zmodyfikowaniu

W klasyfikacji tej STP jest zaliczana do klasycznych teorii prawdy (w duchu Arystotelesa), lecz nie do korespondencyjnych teorii prawdy, które odróżnia pojęcie „mocnej” korespondencji lub konwergencji między językiem a rzeczywistością. 
paradoksu kłamcy tak, aby nie łamał konwencji $T$ - taką modyfikację nazwiemy „poprawnym” paradoksem kłamcy, gdyż jest on przekształcony tak, by przestrzegać warunków definiowania prawdy Tarskiego ${ }^{25}$.

Aby nadać przejrzystość dalszym rozważaniom w tej podsekcji, każdy poziom języka będzie wyróżniony odrębnym stylem pisowni:

J - wszystkie wyrażenia J będą zapisywane kursywą

MJ - wszystkie wyrażenia MJ będą zapisywane z podkreśleniem pojedynczym

MMJ - wszystkie wyrażenia MMJ będą zapisywane z podwójnym podkreśleniem

Można teraz jeszcze raz spojrzeć na zdanie (3) z uwzględnieniem wprowadzonego sposobu zapisu różnych stopni języka. A więc próbując wyrazić (3) w J otrzymuje się:

(3) $\neg T(3)$

Tak sformułowane wyrażenie trzeba znowu odrzucić jako PZW, gdyż J nie zawiera żadnego predykatu prawdziwości T. Nawet gdyby J zawierał jednak jakiś predykat prawdziwości, to zgodnie z konwencją $T$ Tarskiego nie można by go stosować do zdań J.

Można natomiast przenieść te rozważania „o poziom wyżej” to jest rozważyć (3) w MJ. Wówczas otrzymuje się:

(4) ᄀ그 $\mathrm{T}_{\underline{1}}(3)$

Zdanie (4), wyrażone w MJ, mówi, że nie jest prawdą ( $\left.\mathrm{T}_{1}\right)$, że (3). Można to zapisać w następujący sposób:

$$
\text { *(4) } \underline{\mathrm{T}}_{\underline{1}}(\neg T(3))
$$

Numeracja zdań wyraźnie pokazuje, że to zdanie nie odnosi się do siebie, lecz do zdania (3), czyli zdania języka J. Zatem zdanie (4) będzie prawdziwe, bo w rzeczy samej jest tak, że (3) nie jest prawdziwe w sensie $\mathrm{T}_{1} \mathrm{w} \mathbf{M J}$, bo nie jest PZW. Innymi słowy, (3) nie jest poprawnym wyrażeniem J, ale za to (4) jest poprawnym wyrażeniem MJ i jest prawdziwe $\mathrm{w}$ sensie $\mathrm{T}_{2}$, a więc prawdziwe w MMJ. Trzeba tu zaznaczyć, że

25 Jest to nazwa stworzona na użytek tej pracy, bo taka wersja paradoksu kłamcy, o ile jest mi to wiadome, nie posiada żadnej nazwy w literaturze naukowej. Podobny zarzut został sformułowany szczegółowo na stronie www.carneades.org i omówiony na kanale YouTube, https://www.youtube.com/watch?v=LGsFkSJYmRo (dostęp: 10.11.2020). 
przy uznawaniu zdań MJ za prawdziwe lub fałszywe trzeba już używać MMJ, więc o (4) trzeba powiedzieć, że jest $\mathrm{T}_{2}$-prawdziwe, a nie, że jest $\mathrm{T}_{1}$-prawdziwe.

Można zatem ogłosić, że (3) nie jest PZW oraz że (3) nie jest prawdziwe w MJ, oraz że (4) jest prawdziwe w MMJ bez popadania w sprzeczność, gdyż te zdania są odmiennymi zdaniami na różnych poziomach języka, a predykaty prawdziwości na tych poziomach różnią się od siebie. A gdyby i to zdanie poddać „próbie kłamcy”? Spróbujmy przenieść te rozważania jeszcze jeden poziom wyżej, na MMJ:

\section{(5) $\underline{\underline{\neg}} \underline{\underline{\underline{T}}} \underline{\underline{(4)}}$}

Można to przeczytać następująco: nie jest $\mathrm{T}_{2}$-prawdą, że nie jest $\mathrm{T}_{1}$-prawdą, że (3). Podstawiając za wszystkie oznaczenia zdań zdania w językach, w których są one wyrażone, otrzymuje się:

$$
\text { *(5) } \underline{\underline{\neg}}_{\underline{\underline{T}}} \underline{\underline{\left(\neg \mathrm{T}_{1}\right.}}(\neg T(3) \underline{\underline{L}} \underline{\underline{1}}
$$

Gdy czytelnik przyjrzy się uważnie zdaniu (5), to z pewnością dojdzie do wniosku, że nie jest ono $\mathrm{T}_{3}$-prawdziwe, bo (4) jest w istocie $\mathrm{T}_{2}$-prawdziwe, jak to zostało pokazane powyżej. Żeby jednak orzec o prawdziwości (5), trzeba użyć MMMJ i właściwego dlań predykatu prawdziwości, czyli $\mathrm{T}_{3}$ i tak dalej. Można to zapisać w postaci następującej tabeli:

Tabela 1. Analiza „poprawnego" paradoksu kłamcy w J, MJ i MJJ

\begin{tabular}{|c|c|c|}
\hline MMJ & MJ & J \\
\hline (5) $\underline{\underline{I}}_{\underline{\underline{2}}}(4)$ & 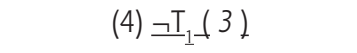 & (3) $\neg T$ (3) \\
\hline $\begin{array}{l}\text { (5) jest } \mathrm{T}_{3} \text { prawdziwe, } \\
\text { bo }\left(\overline{4)} \text { jest } \mathrm{T}_{2} \text {-prawdziwe (dla- }\right. \\
\text { tego, że (3) nie jest } \mathrm{T}_{1} \text {-praw- } \\
\text { dziwe, gdyż nie jest PZW) }\end{array}$ & $\begin{array}{l}\text { (4) jest } T_{2} \text {-prawdziwe, bo (3) } \\
\text { nie jest } P Z W \text {, a więc nie może } \\
\text { być } T_{1} \text {-prawdziwe }\end{array}$ & $\begin{array}{c}\text { (3) nie jest PZW, bo J nie } \\
\text { zawiera takiego predykatu } \\
\text { jak T }\end{array}$ \\
\hline
\end{tabular}

Dochodzi się zatem tutaj do pozornie paradoksalnego wniosku, że zdanie, które na pierwszym poziomie języka nie jest poprawnie zbudowane, w przekładzie na język wyższego rzędu (MJ) jest fałszywe ( $\mathrm{T}_{1}$-fałszywe), zaś w języku następnego rzędu (MMJ) jest prawdziwe ( $\mathrm{T}_{2}$-prawdziwe), a na jeszcze kolejnym poziomie (MMMJ) znowu fałszywe ( $\mathrm{T}_{3}$-fałszywe). Można spodziewać się, że ten wzór będzie się powtarzał „w trakcie wstępowania na metajęzyki wyższych poziomów”. Stanowić 
ma to zarzut, że wedle teorii Tarskiego to samo zdanie jest fałszywe i prawdziwe jednocześnie w zależności od tego, którego metajęzyka się używa

Pozór paradoksalności leży w tym, że za każdym razem, gdy mówi się o prawdziwości jakiegoś zdania, w kolejnych językach używa się innego predykatu prawdziwości i ocenia się różne zdania. Dlatego zarzut ten jest tylko pozornie paradoksalny, bo nie jest tak, że zdanie raz jest prawdziwe, a raz fałszywe, w zależności od przekładu na poziom języka. Należy zauważyć, że po pierwsze, za każdym razem orzekamy o innym zdaniu, a po drugie - zgodnie z zasadą relatywizacji prawdy do języka w każdym języku orzekamy coś „innego” (inną prawdziwość). Zatem zarzut ten - choć jest bardzo pomysłowo zbudowany i rozumowanie nie łamie konwencji $T$ - wcale nie prowadzi do sprzeczności, lecz jest li tylko nieintuicyjny.

Oto jak rozwiązanie Tarskiego funkcjonuje w kontekście klasycznego paradoksu kłamcy oraz „poprawnego” paradoksu kłamcy. Na razie zostało pokazane, dlaczego wedle Tarskiego STP jest niesprzeczna z klasycznym paradoksem kłamcy (dyskwalifikując antynomie jako niepoprawnie zbudowane wyrażenia), a także wówczas, gdy chce się zbudować ten paradoks, zachowując zasady poprawnego budowania wyrażeń (zarzut prowadzi tylko do pozornego paradoksu). Przechodzę do analizy drugiej modyfikacji paradoksu kłamcy.

\section{"Wzmocniony" paradoks kłamcy}

Ta wersja paradoksu stanowi niejako odpowiedź na rozwiązanie paradoksu przez Tarskiego i na wiele innych rozwiązań. Zarzut ten można bowiem podnieść przeciwko wszystkim rozwiązaniom antynomii kłamcy typu (C), czyli takim, które z jakiegoś powodu odrzucają wyrażenie paradoksalne, uznając je na przykład za "niepoprawnie sformułowane” lub „nieznaczące” albo „niebędące zdaniem” i tak dalej. Dlatego nazywa się go „wzmocnionym”, gdyż w ten sposób „ufortyfikowany” paradoks ma być groźny dla wszystkich podobnych rozwiązań ${ }^{26}$. Oto jak wygląda on na przykładzie STP - niech zdania (1) i (2) będą wyrażone w MJ:

26 W języku polskim nazywa się go też „Wzmocnionym Kłamcą” - od angielskiej nazwy: Strenghtened Liar (Brożek, „Rola paradoksu kłamcy w konstrukcji logicznych teorii prawdy", 3; Woleński, Epistemologia, 205). Inna nazwa w literaturze anglosaskiej to Liar's Revange Paradox (zemsta paradoksu kłamcy). 
(1) Zdanie (1) nie jest prawdziwe lub jest niepoprawne.

Można to również zapisać następująco:

(2) $\neg \mathrm{T}_{1}(2) \vee \neg \mathrm{PZW}(2)$

Ponieważ predykat $\mathrm{T}_{1}$ może odnosić się tylko do zdań J, według Tarskiego to zdanie trzeba uznać za niepoprawnie zbudowane wyrażenie metajęzyka ( $\neg$ PZW). A skoro tak, to drugi człon alternatywy wyrażonej w (2) jest spełniony, a więc wydaje się, że (2) musi być jednak prawdziwe. A jeśli jest prawdziwe, to musi być poprawnie zbudowanym wyrażeniem metajęzyka. Dochodzi się więc do sprzeczności, uznając to samo zdanie jednocześnie za poprawnie i niepoprawnie zbudowane wyrażenie.

W ten sam sposób można postąpić ze wszystkimi innymi rozwiązaniami. Wystarczy w miejsce drugiego członu alternatywy (PZW) podstawić tę kategorię, którą przypisuje się antynomii kłamcy (np. „nieznaczące”, „niebędące zdaniem”, „bezsensowne” itp.).

Jak można ominąć ten paradoks z pozycji STP? Trzeba uznać (co jest zakładane w konwencji T), że orzekanie o poprawności składni zdania jakiegoś języka musi się odbywać w jego metajęzyku. Niech PZW, będzie oznaczać „poprawnie zbudowane wyrażenie w J” wyrażone w MJ (i analogicznie do predykatu $\mathrm{T}_{1}$ będzie się go używać w MJ), a PZW ${ }_{\mathrm{MJ}}$ Oznacza „poprawnie zbudowane wyrażenie w MJ” (analogicznie do predykatu $\mathrm{T}_{2}$ będzie się go używać w MMJ). A więc PZW $(\mathrm{P})$ będzie się czytać jako “zdanie p jest poprawnie zbudowanym wyrażeniem” w J. Rozważmy jeszcze raz „wzmocniony” paradoks kłamcy wyrażony w MJ, uwzględniając teraz wprowadzony predykat poprawności:

$$
\text { (3) } \neg \mathrm{T}_{1}(3) \vee \neg \mathbf{P Z W}_{1}(3)
$$

Tego zdania nie można uznać za PZW $\mathbf{M J}_{\mathrm{MJ}}$ gdyż predykat $\mathrm{T}_{1}$ nie może odnosić się do zdania, które zawiera $\mathrm{T}_{1}$. Ponieważ PZW ${ }_{\mathrm{MJ}}$ nie występuje w tym zdaniu, może się wydawać, że nie ma paradoksu. Można jednak postawić pytanie, czy (3) jest $\mathbf{P Z W}$ ? Oczywiście, że nie, bo predykat $\mathrm{T}_{1}$ odnosi się do J, nie zaś do MJ. A zatem (3) jest $\mathrm{T}_{1}$-prawdziwe, bo drugi człon zdania jest spełniony. A skoro (3) jest $\mathrm{T}_{1}$-prawdziwe, to musi być jednocześnie $\mathbf{P Z W} \mathbf{M J}_{\mathrm{MJ}}$, co jest sprzeczne, bo (3) nie może być PZW ${ }_{\mathrm{MJ}}$. Aby ominąć ten paradoks, trzeba by uznać istnienie jakiejś trzeciej wartości, która nie byłaby $\mathbf{P Z W}$, ani nie byłaby $\neg \mathbf{P Z W}$.

Wprowadzenie trzeciej wartości jest jednak nie do utrzymania na tej samej zasadzie, co wprowadzenie trzeciej wartości logicznej (zostało 
to zademonstrowane na przykładzie logiki trójwartościowej) ${ }^{27}$. Wtedy podział zdań wyglądałby następująco:

- poprawnie zbudowane

- prawdziwe

- fałszywe

- niepoprawnie zbudowane

- ani poprawnie zbudowane, ani niepoprawnie zbudowane.

Wówczas można by zbudować kolejną wersję „wzmocnionego” paradoksu kłamcy o postaci:

(4) Zdanie (4) nie jest prawdziwe lub nie jest poprawnie zbudowane, lub nie jest ani poprawnie zbudowane, ani niepoprawnie zbudowane

Następnie, należałoby wprowadzić jeszcze jedną nową wartość. Tworząc w ten sposób kolejne zdania paradoksalne w stylu (3) i (4), wytwarza się nieskończoną ilość nowych wartości.

Czy można w jakiś sposób wybronić STP Tarskiego przed tą antynomią? Odpowiedź powinna brzmieć w następujący sposób: wszystkie przedstawione wyżej wersje „wzmocnionego” paradoksu kłamcy są niepoprawnie zbudowanymi wyrażeniami, więc w ogóle nie podlegają analizie - łamią konwencję $T$, mieszając ze sobą język i metajęzyk. Wyrażenia $\mathrm{w}$ nim zawarte nie powinny być w ogóle rozważane, a paradoks wynika stąd, że wydają się one zrozumiałe. Aby to uwidocznić, można zmodyfikować nieco przytoczony wcześniej przykład dotyczący podstawowego paradoksu kłamcy:

$\left(\mathrm{f}^{\star}\right)$ Zdanie $\left(\mathrm{f}^{\star}\right)$ nie jest vrai lub nie jest bien formulé.

Na tym przykładzie widać, że „wzmocniony” paradoks kłamcy w ogóle nie podlega dalszej analizie $z$ tego prostego powodu, że nie może być zrozumiany, bo jest zbudowany niezgodnie $\mathrm{z}$ regułami syntaktycznymi.

Niech język francuski (F) będzie metajęzykiem języka polskiego (P), a zatem sformułowania vrai i bien formulé, należące do $\mathbf{F}$, orzekają o prawdziwości P-wyrażeń. W F ocenia się to zdanie jako pas bien for$m u l e^{28}$ i nie analizuje się jego treści, bo jest ono zbudowane niezgodnie ze

27 Bardziej obszerną analizę tej możliwości przedstawił Woleński, vide: Epistemologia, 206.

$28 \mathrm{~W}$ języku francuskim pas jest negacją. 
składnią języka - F jako metajęzyk zawiera w sobie przekład ${ }^{29}$ wszystkich wyrażeń $\mathbf{P}$ na $\mathbf{F}$, a zatem zawiera też pojęcia semantyczne, jak właśnie vrai, bien formulé, faux i tak dalej. Nie można więc w $\mathbf{F}$ zbudować zdania składającego się częściowo z $\mathbf{P}$, lecz jedynie z przekładu wyrażeń $\mathbf{P}$ na $\mathbf{F}$. Jest to reguła syntaktyczna metajęzyka, o której była mowa w zasadach definiowania prawdy.

Należy zatem odrzucić „,wzmocniony” paradoks kłamcy bez konieczności tworzenia kolejnych wartości logicznych ad infinitum. Do paradoksu prowadzi analizowanie zdań, które - choć wydają się być jednorodne semantycznie - łamią konwencję $T$ i jako takie nie powinny być w ogóle zrozumiane. W ten sposób STP daje się wybronić przed zarzutem antynomiorodności, przynajmniej w kontekście tej wersji paradoksu kłamcy.

\section{„Przygodny" paradoks kłamcy}

Poniższy przykład pochodzi z artykułu Bartosza Brożka o roli paradoksu kłamcy w teoriach prawdy ${ }^{30}$ :

(1) Czerwony Kapturek zjadł wilka i to zdanie jest fałszywe.

Zdanie (1) oraz jemu podobne Brożek nazywa „Przygodnym Kłamcą"31. Zakłada się, że pierwszy człon zdania (1) trzeba uznać za fałszywy, gdyż to właśnie wilk zjadł Czerwonego Kapturka. W związku $\mathrm{z}$ tym całe wyrażenie jest fałszywe, bo jeden $\mathrm{z}$ członów koniunkcji jest fałszywy. Można jednak przyjąć taki możliwy świat (lub bajkę), w której było odwrotnie: to Czerwony Kapturek zjadł wilka, a wówczas zdanie (1) prowadzi do paradoksu.

Możliwą odpowiedź ze strony Tarskiego jest dość łatwo sformułować - zdanie (1) łamie konwencję $T$, orzekając swoją prawdziwość o sobie samym, tak samo jak to jest w przypadku antynomii Russella. Trzeba je więc uznać za niepoprawnie zbudowane wyrażenie.

29 W artykule z 1933 roku Tarski wskazywał, że każde zdanie z J zawiera swój przekład w MJ (vide: Tarski, „Pojęcie prawdy w językach nauk dedukcyjnych”, 61). Natomiast w pracy z 1944 roku pisał, że MJ zawiera w sobie wszystkie zdania J, choć nie jest to według niego warunek konieczny do funkcjonowania STP (vide: Tarski, „Semantyczna koncepcja prawdy i podstawy semantyki”, 245). Żeby w ten sposób ominąć „wzmocniony" paradoks kłamcy, trzeba się jednak skłonić do pierwotnego rozwiązania, które „jest obecnie powszechnie stosowane w ekspozycji STP”, Woleński, Epistemologia, 196.

30 Brożek, „Rola paradoksu kłamcy w konstrukcji logicznych teorii prawdy”, 2.

31 Brożek nazywa go „Przygodnym Kłamcą” za angielską nazwą Contingent Liar (Brożek, „Rola paradoksu kłamcy w konstrukcji logicznych teorii prawdy”, 2). 
Można jednak nieco rozwinąć ten rodzaj paradoksu: niżej przedstawione zostaną dwa podobne przykłady, które z braku innego terminu również będzie się tu nazywać „przygodnymi”, ignorując drobną różnicę między nimi a przytoczonym paradoksem z udziałem Czerwonego Kapturka $^{32}$.

\section{„Przygodny" paradoks kłamcy (I)}

Oto są dwa kawałki papieru, jeden trzymany w prawej dłoni, drugi w lewej. Na pierwszej kartce jest napisane: „W Krakowie latają smoki”, a na drugiej: „Zdanie napisane na kartce trzymanej w prawej dłoni jest fałszywe”. Trzeba zauważyć, że w tym przykładzie wcale nie miesza się stopni języka - jak to jest w przykładzie z Czerwonym Kapturkiem zdanie dotyczące krakowskich smoków jest wyrażone w języku przedmiotowym, a zdanie stwierdzające jego fałszywość jest wyrażone w jego metajęzyku.

Co się stanie, gdy zamieni się karteczki miejscami? Wówczas w prawej dłoni znajdzie się karteczka $\mathrm{z}$ napisem „Zdanie napisane na kartce trzymanej w prawej dłoni jest fałszywe” - i znów dochodzi się do paradoksu kłamcy. W ten sposób przestrzenne położenie kartki wpływa na prawdziwość zdania, a to wydaje się być (przynajmniej intuicyjnie) absurdalne (zależnie od tego jak rozumie się zależność kontekstową). Wszak intuicja każe raczej oczekiwać od teorii prawdy, że zdania prawdziwe będą prawdziwe bez względu na to, gdzie zostały zapisane i co się $\mathrm{z}$ nimi stało, a więc na ich przygodne umiejscowienie. A oto podobny, lecz nieco bardziej wyraźny przykład „przygodnego” paradoksu kłamcy:

\section{„Przygodny" paradoks kłamcy (II)}

Wyobraźmy sobie obserwatora $O$, przebywającego w pokoju, w którym na tablicy widnieje napis: „Zdanie napisane na tablicy w pokoju o numerze 8 jest fałszywe”. $O$, znając język polski, ocenia ten zapis jako poprawnie zbudowane zdanie języka polskiego. Zakładając, że $O$ nie wie, jaki jest numer pokoju, w którym przebywa, nie może wiedzieć, czy jest ono poprawnie zbudowane, choć zna ten język, co wydaje się być

32 O ile jest mi to wiadome, to taka modyfikacja paradoksu kłamcy również nie ma własnej nazwy w literaturze - można ją jednak określać jako przygodną, gdyż o paradoksalności decyduje tutaj przygodny fakt. 
sprzeczne $z$ intuicją, jaką na ogół wiąże się z teorią prawdy i teorią zdań. Załóżmy, że na tablicy w pokoju o numerze 8 jest zapisane: „Pegazy istnieją”. Wówczas zdanie, które $O$ ma przed sobą, jest prawdziwe. Ale jeśli to $O$ przebywa w pokoju o numerze 8 , to zdanie napisane na tablicy jest paradoksalne (według STP, „niepoprawnie sformułowane”).

Przytoczony przykład ma pokazać, że - jeśli zaakceptuje się STP Tarskiego - nie można ocenić zdania pod kątem tego, czy jest dobrze sformułowane, gdyż nie jest wiadome, do czego dokładnie się ono odnosi. To z kolei kłóci się z intuicją, że reguły syntaktyczne funkcjonują niezależnie od semantyki, czyli że poprawność gramatyczną zdania można ocenić po jego elementach - niezależnie od referencji.

Taki argument jest skierowany również przeciwko rozwiązaniom typu (C), a więc stwierdzeniu, że antynomiorodne zdania nie są poprawnie zbudowane. Wystarczy jednak zwrócić uwagę, że owa intuicja, która każe oceniać poprawność zdania niezależnie od referencji wcale nie jest słuszna. Można przecież wynaleźć takie przypadki zdań w języku potocznym, które również - w zależności od tego, co oznaczają - mogą być po prostu bezsensowne. Weźmy taki przykład: „Kuba siedzi w fotelu”. Zdanie to oczywiście ma sens i może być prawdziwe, jeśli nazwa „Kuba” oznacza dla nas człowieka o imieniu Jakub. Jeśli jednak chodziłoby o państwo w Ameryce Środkowej, to owo zdanie stałoby się jawnie bezsensowne.

W przytoczonym przykładzie widać, że wcale nie jest tak, że zdania można oceniać za poprawnie zbudowane wedle reguł danego języka bez uwzględnienia jego znaczenia - syntaktyka pozostaje w tym sensie odrębna od semantyki, że może określić warunki, pod którymi zdania są poprawnie zbudowane lub nie, ale to, czy dane zdanie rzeczywiście spełnia te warunki może być zależne od jego referencji. Można więc oddalić ten zarzut wobec STP, powołując się na to, że w ten sposób funkcjonuje język w ogóle i nie jest to tylko konsekwencja konwencji $T$.

\section{„Kołowy" paradoks kłamcy}

Kolejna wersja paradoksu kłamcy stanowi niemałe wyzwanie dla STP Alfreda Tarskiego, a dokładniej - podobnie jak poprzednie paradoksy dla zasad, które Tarski przyjmuje celem uniknięcia paradoksu, to jest stratyfikacji języka i jednorodności semantycznej.

Przykład „kołowego” paradoksu był już wcześniej przedstawiony jako paradoks Jourdaina, w którym dwa zdania wzajemnie „zapętlają się” tak, 
że prowadzą do sprzeczności - stąd nazwa „kołowy”33. Oto nieco zmodyfikowana wersja tego paradoksu, przedstawiona przez Saula Kripkego jako argument przeciwko STP ${ }^{34}$ :

Załóżmy, że Jones stwierdza:

(A) Większość stwierdzeń Nixona o Watergate to fałsz ${ }^{35}$.

Widać, że zdanie (A) nie ma w sobie nic „podejrzanego” pod względem łamania konwencji $T^{36}$. Aby przekonać się, czy (A) jest prawdziwe, trzeba policzyć wypowiedzi Nixona o Watergate i sprawdzić stosunek prawdziwych do fałszywych. Załóżmy teraz, że ilość prawdziwych i fałszywych stwierdzeń Nixona o Watergate jest sobie równa i pozostaje do rozstrzygnięcia jedno zdanie, które przesądzi o prawdziwości (A), a brzmi ono tak:

(B) Wszystko, co Jones twierdzi o Watergate, jest prawdziwe.

Jeśli więc (A) jest prawdziwe, to (B) jest fałszywe, ale wtedy (A) musi być fałszywe, co jest sprzeczne. Jeśli zaś (A) jest fałszywe, to (B) jest prawdziwe, a wtedy $(\mathrm{A})$ również musi być prawdziwe, co także jest sprzeczne.

Również Tarski podał przykład paradoksu „kołowego” generującego sprzeczność w ten sam sposób, co paradoksy Jourdaina i Kripkego.

Wyobraźmy sobie książkę, która ma 100 stron, a na każdej stronie wydrukowane jest tylko jedno zdanie. Na 1 stronie czytamy: „zdanie wydrukowane na stronie 2 tej książki jest prawdziwe”. Na stronie 2 czytamy: „zdanie wydrukowane na stronie 3 tej książki jest prawdziwe”. To samo powtarza się aż do strony 99. Na stronie 100, ostatniej stronie książki, znajdujemy natomiast: „zdanie wydrukowane na stronie 1 tej książki jest fałszywe" 37 .

Zarzut Kripkego, który można z powodzeniem rozciągnąć na wszystkie trzy przykłady paradoksu, polega na wykazaniu niemożliwości wskazania, które ze zdań jest wyrażone w J, a które w $\mathbf{M J}{ }^{38}$. Można go sformu-

33 ang. Cyclical Liar.

34 Saul Kripke, "Outline of a Theory of Truth", The Journal of Philosophy 19 (1975): 691.

35 Dla uproszczenia przyjmuje się, że (A) to jedyne zdanie, które Jones wypowiedział.

36 Na marginesie można dodać, że sam Tarski pisał o tym, że pojęcie prawdy jest niezbędne do formułowania sądów w dziedzinie historii, vide: Tarski „Prawda i dowód”, 310-311.

37 Tarski „Prawda i dowód”, 305.

38 Kripke, "Outline of a Theory of Truth", 695-696. 
łować następująco: „jak można mówić, że jakiś ciąg wypowiedzi miesza ze sobą poziomy języka, jeśli nie sposób jednoznacznie przypisać im tych poziomów?".

Odpowiedź na ten zarzut - a więc na trzy paradoksy „kołowe” - jest dość prosta. W tych konstrukcjach (Jourdaina, Kripkego i Tarskiego) nie da się określić poziomów języka w taki sposób, żeby móc stwierdzić, czy zdania, które mówią o innych zdaniach jakiegoś języka, należą rzeczywiście do jego metajęzyka (a więc, czy zdania, które mówią o innych, leżą ,jedno oczko wyżej” w hierarchii języków). Zatem niemożliwe jest sprawdzenie, czy ów ciąg zdań spełnia reguły syntaktyczne, innymi słowy, czy każde z rozważanych zdań jest poprawnie zbudowanym wyrażeniem (to znaczy spełnia T-schemat: (T) Zdanie $X$ jest prawdziwe wtedy i tylko wtedy, gdy $p$, gdzie $X$ jest nazwą zdania, o którego prawdziwość chodzi, a symbol $p$ oznacza przekład tego zdania na metajęzyk).

Woleński zauważa z kolei, że paradoks Kripkego łamie regułę „czystości semantycznej", tzn. żadne ze zbudowanych zdań (A) i (B) nie może być wyższego stopnia, gdy to drugie jest wyższego stopnia ${ }^{39}$. Stąd widać, że tego typu antynomie kłamcy nie powodują, że STP rodzi antynomie ukazują one raczej pewne skrajne przypadki, gdy konwencja $T$ zakazuje pewnych, nie zawsze oczywistych, konstrukcji zdaniowych.

Tutaj można rozważyć jeszcze jedną wersję paradoksu kłamcy, która choć stricte nie jest „kołowa” - ma bardzo podobną strukturę do wyżej wymienionych. Paradoks ten został sformułowany przez Stephena Yablo i określa się go właśnie nazwiskiem autora ${ }^{40}$ :

\section{Paradoks Yablo:}

1. Wszystkie zdania poniżej są fałszywe

2. Wszystkie zdania poniżej są fałszywe

3. Wszystkie zdania poniżej są fałszywe

4. Wszystkie zdania poniżej są fałszywe

5. Wszystkie zdania poniżej są fałszywe

6. Wszystkie zdania poniżej są fałszywe

7. Wszystkie zdania poniżej są fałszywe

8. Wszystkie zdania poniżej są fałszywe

9. Wszystkie zdania poniżej są fałszywe

39 Woleński, Epistemologia, 205.

40 Stephen Yablo, "Paradox without Self-Reference”, Analysis 53 (1993). 
W tym przykładzie każde zdanie mówi coś o zdaniach niżej od niego, a te ciągną się w nieskończoność. Wyjątkowość tej formuły polega na tym, że nie zamyka się tego ciągu zdań, a więc nie ma tutaj pętli semantycznej, ale jest to paradoks, bo przy dowolnym wartościowaniu dochodzi się do sprzeczności.

Jeśli bowiem wszystkie zdania poniżej (1) są fałszywe, to pierwsze zdanie jest prawdziwe. A skoro jest tak, jak stwierdza (1), to wówczas (2) również staje się prawdziwe (bo wszystkie pod nim są fałszywe). Jednak jeśli (2) jest prawdziwe, to (1) przestaje być prawdziwe. I tak wszystkie kolejne zdania również muszą być prawdziwe, a to prowadzi do sprzeczności.

Możliwą replikę ze stanowiska STP na tę antynomię można sformułować następująco: w tym przykładzie nie da się w ogóle określić poziomów języka. Aby to uczynić, trzeba by zacząć od określenia poziomu ostatniego zdania, by móc „przejść w górę listy” tych zdań. Skoro jednak zdania powstają w nieskończoność, to zadanie jest niemożliwe.

\section{Podsumowanie}

Oto jak rozwiązanie paradoksu kłamcy w STP funkcjonuje w rozbudowanych wersjach paradoksu kłamcy. Niektóre z nich wydawały się poważnie zagrażać trafności teorii Tarskiego, ale zostało wyżej wykazane, że STP daje się wybronić przed zarzutem antynomiorodności. Przywołane przykłady demonstrują jednak wyraźnie słabe strony tej teorii, a konkretnie konwencji $T$ - fakt, że czasem nie można ocenić, czy dana wypowiedź jest poprawnie zbudowana bez poznania jej referencji lub że w niektórych przypadkach nie można w ogóle określić poziomów użytych języków, stanowi niemałe ograniczenie STP. Jest to jednak - jak współcześnie podkreślają badacze ${ }^{41}$ - najprostsze z proponowanych w tej sprawie rozwiązań. Hierarchia języków i zasada jednorodności (czystości) semantycznej są nieodzowne, jeśli chce się pozostać w obrębie logiki klasycznej i w prosty sposób ominąć antynomie semantyczne.

W niniejszej pracy zostało pokazane, jak semantyczna teoria prawdy reaguje na różnego typu antynomie semantyczne oraz że pozostaje ona odporna na różnego rodzaju zarzuty, które w większości przybierają postać rozbudowanego paradoksu kłamcy. Odporność STP na te

41 Oprócz wymienianych wcześniej prac Woleńskiego, Łukowskiego i Rudnickiego należy przywołać jeszcze najważniejszą monografię wydaną w ostatnich latach w języku polskim, poświęconą paradoksom, tj. Piotr Łukowski, Paradoksy (Łódź: Wydawnictwo Naukowe Uniwersytetu Łódzkiego, 2006). 
antynomie jest niewątpliwie osiągnięciem dla logiki, gdyż antynomie o ile są „niegroźne” w języku potocznym - stanowią poważne wyzwanie dla nauk dedukcyjnych i wymagają poważnego potraktowania. Zatem można stąd wyciągnąć wniosek, że STP ma doniosłe znaczenie dla logiki z tego powodu, że umożliwia wprowadzenie pojęcia prawdy do języków sformalizowanych i jednocześnie nie jest antynomiorodna. Wymaga to oczywiście przyjęcia wielu - nie zawsze oczywistych - założeń, jak konwencja $T$. Stanowi to jednak niedużą cenę, którą trzeba zapłacić za możliwość niesprzecznego używania pojęcia prawdy. Cena ta, jak wyżej starałem się pokazać, jest najmniejszą z możliwych, a to czyni STP najbardziej atrakcyjną z teorii prawdy na gruncie klasycznych teorii prawdy.

\section{Bibliografia}

\section{Książki i monografie}

Borkowski Ludwik, Wprowadzenie do logiki i teorii mnogości (Lublin: Towarzystwo Naukowe Katolickiego Uniwersytetu Lubelskiego, 1991).

Jonkisz Adam, „Semantyczne ujęcie klasycznej koncepcji prawdy”, w $O$ prawdzie, t. I, (Cieszyn: Koło Filozoficzne Uniwersytetu Śląskiego w Cieszynie, 1992).

Łukowski Piotr, Paradoksy (Łódź: Wydawnictwo Naukowe Uniwersytetu Łódzkiego, 2006).

Nowaczyk Adam, „Co naprawdę powiedział Tarski o prawdzie w roku 1933?”, w Alfred Tarski: dedukcja i semantyka, (Warszawa: Wydawnictwo Naukowe Semper, 2003), 61-66.

Tarski Alfred, „Pojęcie prawdy w językach nauk dedukcyjnych”, w idem, Pisma logiczno-filozoficzne, t. I, (Warszawa: Wydawnictwo Naukowe PWN, 1995), 13-172.

Tarski Alfred, „List Alfreda Tarskiego do Ottona Neuratha”, w idem, Pisma logiczno-filozoficzne, t. I, (Warszawa: Wydawnictwo Naukowe PWN, 1995), 206-213.

Tarski, Alfred. „Semantyczna koncepcja prawdy i podstawy semantyki”, w idem, Pisma logiczno-filozoficzne, t. I, (Warszawa: Wydawnictwo Naukowe PWN, 1995), 228-282.

Tarski Alfred, „Prawda i dowód”, w idem, „Pisma logiczno-filozoficzne, t. I, (Warszawa: Wydawnictwo Naukowe PWN, 1995), 292-332.

Wittgenstein Ludwig, Uwagi o podstawach matematyki, tłum. Marcin Poręba, (Warszawa: Wydawnictwo KR, 2000).

Woleński Jan, Epistemologia (Warszawa: Wydawnictwo Naukowe PWN, 2005). 


\section{Czasopisma}

Brożek Bartosz, „Rola paradoksu kłamcy w konstrukcji logicznych teorii prawdy", Zagadnienia Filozoficzne w Nauce 15 (2002): 48-88.

Kripke Saul, "Outline of a Theory of Truth", The Journal of Philosophy 19 (1975): 690-716.

Łukowski Piotr, “Content Implication and Yablo’s Sequence of Sentences”, Logic and Logical Philosophy 29 (2020): 57-69.

Mankowitz Poppy, „The Liar Without Relativism”, Erkenntnis (2021): 1-22.

Pruś Jakub, „Teorie prawdy: klasyczna, korespondencyjna i semantyczna - próba uściślenia relacji”, Rocznik Filozoficzny Ignatianum 24/2 (2018): 57-83.

Rudnicki Konrad, Łukowski Piotr, "Psychophysiological Approach to the Liar Paradox: Jean Buridan's Virtual Entailment Principle Put to the Test”, Synthese 198 (2021): 5573-5592.

Yablo Stephen, "Paradox without Self-Reference", Analysis 53 (1993): 251-252.

\section{Źródła internetowe}

"Alfred Tarski and the Liar's Paradox", www.carneades.org, https://www.youtube. com/watch?v=LGsFkSJYmRo (dostęp: 10.11.2020).

Woleński Jan, Pętle semantyczne, referat wygłoszony na seminarium „Filozofia w nauce", https://www.youtube.com/watch?v=cR9DU9FkAJo (dostęp: 10.11.2020). 